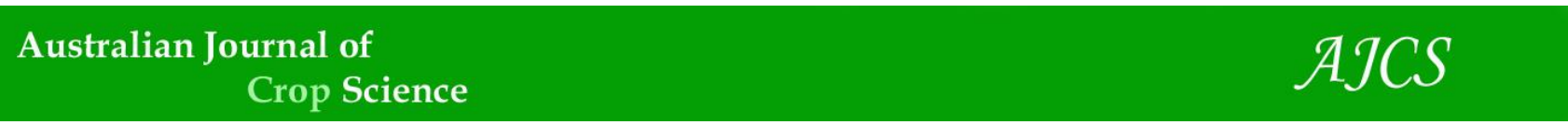

AJCS 15(12):1435-1441 (2021)

ISSN:1835-2707

doi: $10.21475 / a j c s .21 \cdot 15 \cdot 12 . p 3310$

\title{
Antixenosis in cotton genotypes (Gossypium hirsutum var. marie galante) to Spodoptera frugiperda (Lepidoptera: Noctuidae) mediated by trichome and gossypol densities
}

\section{Patrícia Vaz da Costa da Silva ${ }^{1}$, Célio Borella Junior ${ }^{1}$, Flávio Gonçalves de Jesus ${ }^{1}$, Lúcia Vieira Hoffmann ${ }^{2}$, Ivandilson Pessoa Pinto de Menezes ${ }^{1 ; 3^{*}}$}

\author{
${ }^{1}$ Instituto Federal Goiano, Campus Urutaí, Programa de Pós-Graduação Profissional em Proteção de Plantas, \\ Rodovia Geraldo Silva Nascimento, 75790-000, Urutaí, Goiás, Brazil \\ ${ }^{2}$ Embrapa Arroz e Feijão, Laboratório de Biotecnologia Vegetal, Santo Antônio de Goiás, 75375-000, Goiás, Brazil \\ ${ }^{3}$ Instituto Federal do Ceará, Campus Acopiara, Rodovia CE 060, Km 332, 63560-000, Acopiara, Ceará, Brazil
}

*Corresponding author: ivandilson.menezes@ifce.edu.br

\begin{abstract}
Cotton (Gossypium hirsutum L.) is one of the most important crops in Brazil and pest incidence limits its yields. The fall armyworm, Spodoptera frugiperda (J.E. Smith) (Lepidoptera: Noctuidae), native to tropical and subtropical America, spread and rapidly became an invasive pest worldwide. It is a polyphagous pest that feeds on up to 353 plant species including cotton. The objective of this study was to evaluate the antixenosis to $S$. frugiperda in 27 cotton genotypes, comparing varieties with non- commercial genotypes. The attractiveness was estimated in no-choice and free-choice tests, offering leaf discs of the 27 cotton genotypes to $S$. frugiperda, and counting the number of caterpillars feeding at 3, 5, 10, 15, and 30 minutes and 1, 2, 6, 12, and 24 hours after their release. The numbers of trichomes and gossypol glands per $\mathrm{cm}^{2}$ were measured on abaxial and adaxial surface. The free-choice test was performed in a randomized block design with the 27 genotypes (treatments) and 20 arenas (replicates). The no-choice assay was conducted as a completely randomized design with 18 genotypes and 20 replicates. The non-commercial genotypes PI0440, CE0467, PI0416, BA0512 and MA0425 presented antixenosis against S. frugiperda. In the free-choice test the cultivar BRS Buriti and the genotype PI0429 were the most attractive to S. frugiperda, while in no-choice test, the genotype PI0429 was the most attractive. High trichome density and gossypol glands did not influence the attractiveness of $S$. frugiperda in cotton genotypes, while the absence of trichomes was repellent to the caterpillars. There is polymorphism among cotton genotypes to attractiveness to the pest, and the genotypes with antixenosis can be used in future study in plant breeding program as donor source of resistance to $S$. frugiperda.
\end{abstract}

Keywords: Attractiveness, Gossypol, Plant Resistance to insect, Trichomes.

Abbreviations: IPM- Integrated Pest Management Programs; UPGMA - Unweighted Pair Group Method with Arithmetic Mean.

Introduction

Gossypium hirsutum var. marie galante is an arboretum cotton species with a large center of origin, ranging from Colombian and Venezuelan coasts to the Southeast of El Salvador, the Antilles, and the Semiarid Northeast Brazil (Moreno et al., 2008). In Brazil, G. hirsutum r. marie galante is known as mocó cotton, bearing large variability, and differing to the Central American (Stephens, 1973). In Semiarid Northeast region of Brazil, mocó cotton coexists with the compatible species $G$. barbadense and $G$. mustelinum, leading to natural crosses and increased variability (Menezes et al., 2017; Menezes, 2014; Menezes, 2010).

Mocó cotton represented the largest area planted with cotton in Brazil in the 1970s, all of it in the Northeast region of Brazil, being grown on approximately 2.5 million hectares, for its high fiber quality and drought resistance (Stephens, 1973; Liu and Wendel, 2002; Menezes et al., 2015). The main producers were found in the states of Paraíba, Rio Grande do Norte, Ceará, Piauí, Maranhão, and Pernambuco (Freire, 2007). However, in the 1980s, the cultivated area of mocó cotton was reduced due to economic and political changes, favored also by climatic problems, in addition to the dispersion of the boll weevil (Anthomonus grandis) (Coleoptera: Curculionidae) (Giband et al., 2010; Menezes et al., 2017). From this decade, cotton lines bred from cotton types domesticated in Mexico and cultivated in North America (G. hirsutum var. latifolium) started to be cultivated in Brazilian Cerrado (similar to Savannah) in Central Brazil. Cotton has been one of the most important crops in Brazil, but one of the main factors that limit its sustainability is the incidence of pests (Campos et al., 2012). Among the pests, caterpillars are the second cause of economical loss after boll weevil, even when transgenics are used. Spodoptera frugiperda (Lepidoptera: Noctuidae) causes damage in the vegetative and reproductive phase, feeding on leaves, 
flower, floral bud, and green cotton boll (Moreno et al., 2008; Jesus et al., 2014).

The use of pest resistant cotton cultivars can be adopted as strategy in integrated pest management program - IPM to increase crop sustainability (Baldin et al., 2019). The mainly morphological characteristics reported in cotton plants that confer resistance are: frego bract, absence of nectaries, glabrous plants, gossypol, tannin, leaf and bract color, and okra leaf (Bastos et al., 2008). Detection of resistance traits within traditional or native Brazilian genotypes may lead to insertion of valuable traits in bred varieties (Menezes et al., 2014).

Plant resistance to insects are commonly referred to in three categories: non-preference (antixenosis), antibiosis and tolerance. These types of resistance can cause changes in insect behavior and/or biology (antixenosis and antibiosis) or even a reaction of the plant due resulting in tolerance (Seifi et al., 2013; Smith, 2005).

The study involving plant resistance to insects in cotton is limited to commercial cultivars in Brazil. Campos et al. (2012) observed lower attractiveness of S. frugiperda in the cultivars BRS Acala-90, Fibermax-966 and DeltaPenta, BRS Cedro, BRS Itamarati 90, Coodetec 408 and BRS Aroeira. Jesus et al. (2014) observed antibiosis in the cultivar NuOpal ${ }^{\circledR}$ to $S$. frugiperda and the caterpillars and pupae reared on this cultivar had their biology negatively affected. Given the scarcity of studies evaluating the resistance of local cotton varieties to $S$. frugiperda due the importance of these materials in plant breeding program as donor source of resistance, the objective this study was to evaluate the antixenosis in 27 cotton genotypes to $S$. frugiperda.

\section{Results}

\section{Antixenosis}

The mocó genotypes collected in farms or backyards (Table 1) PI0440, CE0467, MA0423, RN0512, MA0430, MA0409, BA0502, MA0418, CE0461, MA0438, PI0467, and AC0602 and the cultivars BRS Cedro and IAC 25 were the least attractive to $S$. frugiperda in free-choice test, and the mocó cotton PI0429, the most attractive (Table 2).

In the no-choice test, the collected genotypes PI0467, RN0512, MA0418, MA0425, MA0438, MA0409, BA0477, CE0474, PI0416, CE0467, MA0423, PI0440, BA0502, CE0461, BA0512, BA05101, PI0432, PI0438, AC0602 and the variety BRS Cedro were less atractive to $S$. frugiperda than the varieties BRS Buriti and IAC 25 or the collected genotypes PI0429, MA0407, CE0507, PI0433 and MA0430 (Table 2). According to the attractiveness index in both tests, the genotypes RN0512, MA0418, CE0467 and BA0502 were classified as repellent to $S$. frugiperda.

\section{Morphological characteristics}

Trichome densities on the adaxial and abaxial surfaces were greatest in PI0416 genotype (Table 3). The genotypes PI0440, AC0602, RN0512, PI0429, CE0467, PI0432, PI0437, BA05101, IAC25, BA0512, MA0438, MA0418, MA0430, CE0461, MA0407, CE0507, MA0409, CE0474, BA0502, PI0433 and PI0467 and the cultivar BRS Buriti showed the lowest trichome densities on the abaxial surface. The genotypes RN0512, PI0432, PI0429, BA0502, BA0512, CE0467, IAC 25, PI0438, BA05101, MA0438 and the cultivar BRS Buriti, also showed the lowest trichome densities on the adaxial surface. The genotype PI0440 did not present trichomes on any leaf surface.
The genotypes PI0433, CE0507, MA0407, BA0477 and MA0409 and the cultivar BRS Cedro, showed a greatest amount of gossypol glands on the adaxial surface (Table 3). On the abaxial surface, the cultivar BRS Cedro and PI0433, CE0507, BA0477, CE0474, CE0461 and MA0409 genotypes showed highest trichome densities.

The correlation coefficients between trichomes or gossypol glands and attractiveness in free-choice or no-choice tests were not significant, showing that the attractiveness of $S$. frugiperda in cotton genotypes was not influenced by trichome densities or the number of gossypol glands (Table 4).

UPGMA separated the groups by different levels of antixenosis according to attractiveness in free-choice and no-choice tests (Fig. 1; Fig. 2). In free-choice test, the group I was composed by the highly susceptible genotypes: BRS Buriti, PI0429 and PI0433; group II, by the susceptible genotypes: MA0407, CE0507 and MA0430; and group III comprised the moderately resistant genotypes: PI0440, CE0461, MA0423, CE0467, BRS Cedro, RN0512, BA0512, MA0425, CE0474, PI0432, PI0467, BA0477, PI0416, AC0602, PI0437, BA0502, BA05101, IAC 25, MA0418 and MA0409 (Fig. 1).

In non-choice test, the group I, was defined by a single genotype as highly susceptible: PI0429; group III comprised the moderately resistant genotypes: IAC 25, PI0467, MA0418, BRS Cedro, MA0438, PI0437, CE0461, BA0502, MA0409, CE0467, PI0440, MA0430, MA0423 and RN0512; and the intermediary group II was composed by the susceptible genotypes: PI0433, BA05101, AC0602, MA0425, BA0512, MA0407, PI0432, BRS Buriti, CE0474 and PI0416 (Fig. 2).

\section{Discussion}

In free-choice and no-choice tests, the cotton genotypes influenced the attractiveness behavior of $S$. frugiperda.

The genotypes PI0440, CE0467, MA0423, RN0512, MA0430, MA0409, BA0502, IAC 25, MA0418, CE0461, MA0438, PI0467, BRS Cedro and AC0602, which were less attractive to S. frugiperda in free-choice test may not favor the insectplant interaction lacking to stimulate the insect to feed (Baldin et al., 2019). Most herbivorous insects are shown to be attracted by visual, olfactory and other stimuli, based on the physic-chemical characteristics of the plant's surface (Yang et al., 1991). Factors such as visual and olfactory stimuli, may have influenced the process of choice of the insect by the host and resulted in the repellency of $S$. frugiperda.

In no-choice test, the genotypes PI0467, RN0512, MA0418, MA0425, MA0438, MA0409, BRS Cedro, BA0477, CE0474, PI0416, CE0467, MA0423, PI0440, BA0502, CE0461, BA0512, BA05101, PI0432, PI0438 and AC0602 were the least attractive to $S$. frugiperda. Positive and negative stimuli from the plant influenced the feeding behavior, which nature may be of chemical (Hoffmann-Campo et al., 2001), physical (Prado et al., 2015) and/or morphological (Silva et al., 2014). Considering the attractiveness index, the genotypes RN0512, MA0418, CE0467 and BA0502, that were the least preferred by $S$. frugiperda both in free-choice and no-choice tests, thus antixenosis is present. Antixenosis is related to changes in the insect's behavior for feeding, oviposition and shelter promoted by the host plant (Baldin et al., 2019). The cause of antixenosis in plants are due to the presence of chemical substances, which influences the insect's behavior by attracting or repelling and/or due to the plant's 
Table 1. Relationship and origin of cotton genotypes. State of collection by Embrapa and cotton species (https://www.embrapa.br/en/alelo).

\begin{tabular}{|c|c|c|}
\hline Genotype & States of Origin & Species \\
\hline BRS Buriti ${ }^{1}$ & Goiás & G. hirsutum latifolium \\
\hline BRS Cedro $^{1}$ & Piauí & G. hirsutum latifolium \\
\hline IAC $25^{1}$ & São Paulo & G. hirsutum latifolium \\
\hline $\mathrm{ACO}^{2} 2^{2}$ & Acre & G. hirsutum r. marie galante \\
\hline $\mathrm{BA} 0477^{2}$ & Bahia & G. hirsutum r. marie galante \\
\hline${\mathrm{BA} 0502^{2}}^{2}$ & Bahia & G. hirsutum r. marie galante \\
\hline BA05101 ${ }^{2}$ & Bahia & G. hirsutum r. marie galante \\
\hline $\mathrm{BA0512}^{2}$ & Bahia & G. hirsutum r. marie galante \\
\hline CE0461 $^{2}$ & Ceará & G. hirsutum r. marie galante \\
\hline CE0467 ${ }^{2}$ & Ceará & G. hirsutum r. marie galante \\
\hline CE0474 ${ }^{2}$ & Ceará & G. hirsutum r. marie galante \\
\hline CE0507 ${ }^{2}$ & Ceará & G. hirsutum r. marie galante \\
\hline MA0407 & Maranhão & G. hirsutum r. marie galante \\
\hline $\mathrm{MA} 0409^{2}$ & Maranhão & G. hirsutum r. marie galante \\
\hline MA0418 ${ }^{2}$ & Maranhão & G. hirsutum r. marie galante \\
\hline MA0423 ${ }^{2}$ & Maranhão & G. hirsutum r. marie galante \\
\hline $\mathrm{MA} 0425^{2}$ & Maranhão & G. hirsutum r. marie galante \\
\hline $\mathrm{MA} 0430^{2}$ & Maranhão & G. hirsutum r. marie galante \\
\hline MA0438 ${ }^{2}$ & Maranhão & G. hirsutum r. marie galante \\
\hline $\mathrm{PI0416}{ }^{2}$ & Piauí & G. hirsutum r. marie galante \\
\hline $\mathrm{PI} 0429^{2}$ & Piauí & G. hirsutum r. marie galante \\
\hline $\mathrm{PI} 0432^{2}$ & Piauí & G. hirsutum r. marie galante \\
\hline $\mathrm{PI} 0433^{2}$ & Piauí & G. hirsutum r. marie galante \\
\hline $\mathrm{PI} 0438^{2}$ & Piauí & G. hirsutum r. marie galante \\
\hline $\mathrm{PIO440}{ }^{2}$ & Piauí & G. hirsutum r. marie galante \\
\hline $\mathrm{PIO467}^{2}$ & Piauí & G. hirsutum r. marie galante \\
\hline $\mathrm{RN} 0512^{2}$ & Rio Grande do Norte & G. hirsutum r. marie galante \\
\hline
\end{tabular}

${ }^{1}$ Commercial Cultivars. ${ }^{2}$ Mocó cotton (Landraces).

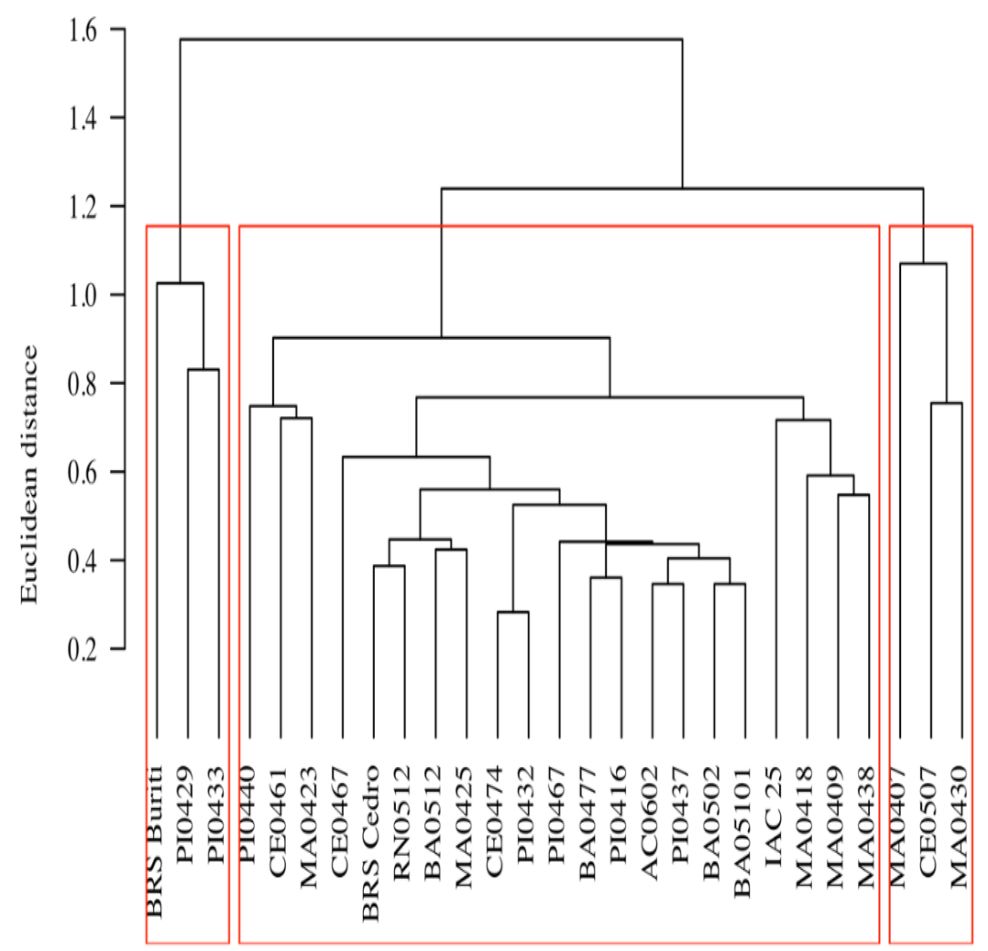

Fig 1. Dendrogram resulting from UPGMA multivariate cluster analysis (Euclidian distance), based on the attractiveness mean of Spodoptera frugiperda (Lepidoptera: Noctuidae) in free-choice test in 27 cotton genotypes. 
Table 2. Mean number of Spodoptera frugiperda (Lepidoptera: Noctuidae) and attractiveness index in free-choice and no-choice tests in 27 cotton genotypes.

\begin{tabular}{|c|c|c|c|c|}
\hline \multirow[t]{2}{*}{ Genotypes } & \multicolumn{2}{|c|}{ Attractiveness } & \multicolumn{2}{|c|}{ Attractiveness index } \\
\hline & Free-choice & No-choice & Free-choice & No-choice \\
\hline IAC25 & $0.16 \pm 0.03 c$ & $0.46 \pm 0.07 a$ & $0.88 \mathrm{D}$ & $1.24 \mathrm{~S}$ \\
\hline MA0430 & $0.11 \pm 0.03 \mathrm{c}$ & $0.50 \pm 0.10 a$ & $0.72 \mathrm{D}$ & $1.28 \mathrm{~S}$ \\
\hline PI0467 & $0.20 \pm 0.02 \mathrm{c}$ & $0.25 \pm 0.06 b$ & $1.00 \mathrm{~N}$ & $0.94 \mathrm{D}$ \\
\hline RN0512 & $0.10 \pm 0.04 \mathrm{c}$ & $0.26 \pm 0.06 b$ & $0.68 \mathrm{D}$ & $0.96 \mathrm{D}$ \\
\hline MA0418 & $0.17 \pm 0.02 \mathrm{c}$ & $0.26 \pm 0.05 b$ & $0.91 \mathrm{D}$ & $0.96 \mathrm{D}$ \\
\hline MA0425 & $0.27 \pm 0.05 b$ & $0.19 \pm 0.05 b$ & $1.14 \mathrm{~S}$ & $0.81 \mathrm{D}$ \\
\hline MA0438 & $0.17 \pm 0.02 \mathrm{c}$ & $0.32 \pm 0.07 b$ & $0.92 \mathrm{D}$ & $1.07 \mathrm{~S}$ \\
\hline BRS Buriti & $0.27 \pm 0.02 b$ & $0.72 \pm 0.09 \mathrm{a}$ & $1.14 \mathrm{~S}$ & $1.44 \mathrm{~S}$ \\
\hline MA0409 & $0.13 \pm 0.04 \mathrm{c}$ & $0.32 \pm 0.07 b$ & $0.78 \mathrm{D}$ & $1.14 \mathrm{~S}$ \\
\hline BRS Cedro & $0.20 \pm 0.02 c$ & $0.28 \pm 0.06 b$ & $1.00 \mathrm{SP}$ & $1.00 \mathrm{SP}$ \\
\hline $\mathrm{PI0429}$ & $0.49 \pm 0.05 \mathrm{a}$ & $0.70 \pm 0.08 a$ & $1.41 \mathrm{~S}$ & $1.44 \mathrm{~S}$ \\
\hline BA0477 & $0.30 \pm 0.04 \mathrm{~b}$ & $0.22 \pm 0.06 b$ & $1.19 \mathrm{~S}$ & $0.88 \mathrm{D}$ \\
\hline CE0474 & $0.29 \pm 0.03 \mathrm{~b}$ & $0.32 \pm 0.06 b$ & $1.17 \mathrm{~S}$ & $1.07 \mathrm{~S}$ \\
\hline MA0407 & $0.37 \pm 0.06 \mathrm{~b}$ & $0.62 \pm 0.07 a$ & $1.29 \mathrm{~S}$ & $1.38 \mathrm{~S}$ \\
\hline PI0416 & $0.26 \pm 0.04 \mathrm{~b}$ & $0.17 \pm 0.05 b$ & $1.13 \mathrm{~S}$ & $0.76 \mathrm{D}$ \\
\hline CE0467 & $0.09 \pm 0.04 \mathrm{c}$ & $0.20 \pm 0.05 b$ & $0.63 \mathrm{D}$ & $0.83 \mathrm{D}$ \\
\hline MA0423 & $0.10 \pm 0.04 \mathrm{c}$ & $0.36 \pm 0.08 b$ & $0.68 \mathrm{D}$ & $1.13 \mathrm{~S}$ \\
\hline PI0440 & $0.09 \pm 0.03 c$ & $0.39 \pm 0.07 b$ & $0.61 \mathrm{D}$ & $1.16 \mathrm{~S}$ \\
\hline BA0502 & $0.15 \pm 0.04 \mathrm{c}$ & $0.23 \pm 0.06 b$ & $0.85 \mathrm{D}$ & $0.90 \mathrm{D}$ \\
\hline CE0461 & $0.17 \pm 0.03 c$ & $0.34 \pm 0.07 b$ & $0.91 \mathrm{D}$ & $1.10 \mathrm{~S}$ \\
\hline BA0512 & $0.34 \pm 0.05 \mathrm{~b}$ & $0.18 \pm 0.06 b$ & $1.25 \mathrm{~S}$ & $0.78 \mathrm{D}$ \\
\hline BA05101 & $0.27 \pm 0.05 b$ & $0.25 \pm 0.50 \mathrm{~b}$ & $1.14 \mathrm{~S}$ & $0.94 \mathrm{D}$ \\
\hline PI0433 & $0.27 \pm 0.05 \mathrm{~b}$ & $0.54 \pm 0.05 a$ & $1.15 \mathrm{~S}$ & $1.32 \mathrm{~S}$ \\
\hline CE0507 & $0.34 \pm 0.03 b$ & $0.61 \pm 0.10 \mathrm{a}$ & $1.25 \mathrm{~S}$ & $1.37 \mathrm{~S}$ \\
\hline PI0432 & $0.30 \pm 0.07 \mathrm{~b}$ & $0.33 \pm 0.06 b$ & $1.19 \mathrm{~S}$ & $1.08 \mathrm{~S}$ \\
\hline PI0438 & $0.11 \pm 0.03 \mathrm{c}$ & $0.31 \pm 0.05 b$ & $0.70 \mathrm{D}$ & $1.05 \mathrm{~S}$ \\
\hline AC0602 & $0.22 \pm 0.02 \mathrm{c}$ & $0.23 \pm 0.08 b$ & $1.05 \mathrm{~S}$ & $0.90 \mathrm{D}$ \\
\hline$F$ & 5.27 & 2.88 & - & - \\
\hline$P$ Value & $<0.0005$ & $<0.0005$ & - & - \\
\hline
\end{tabular}

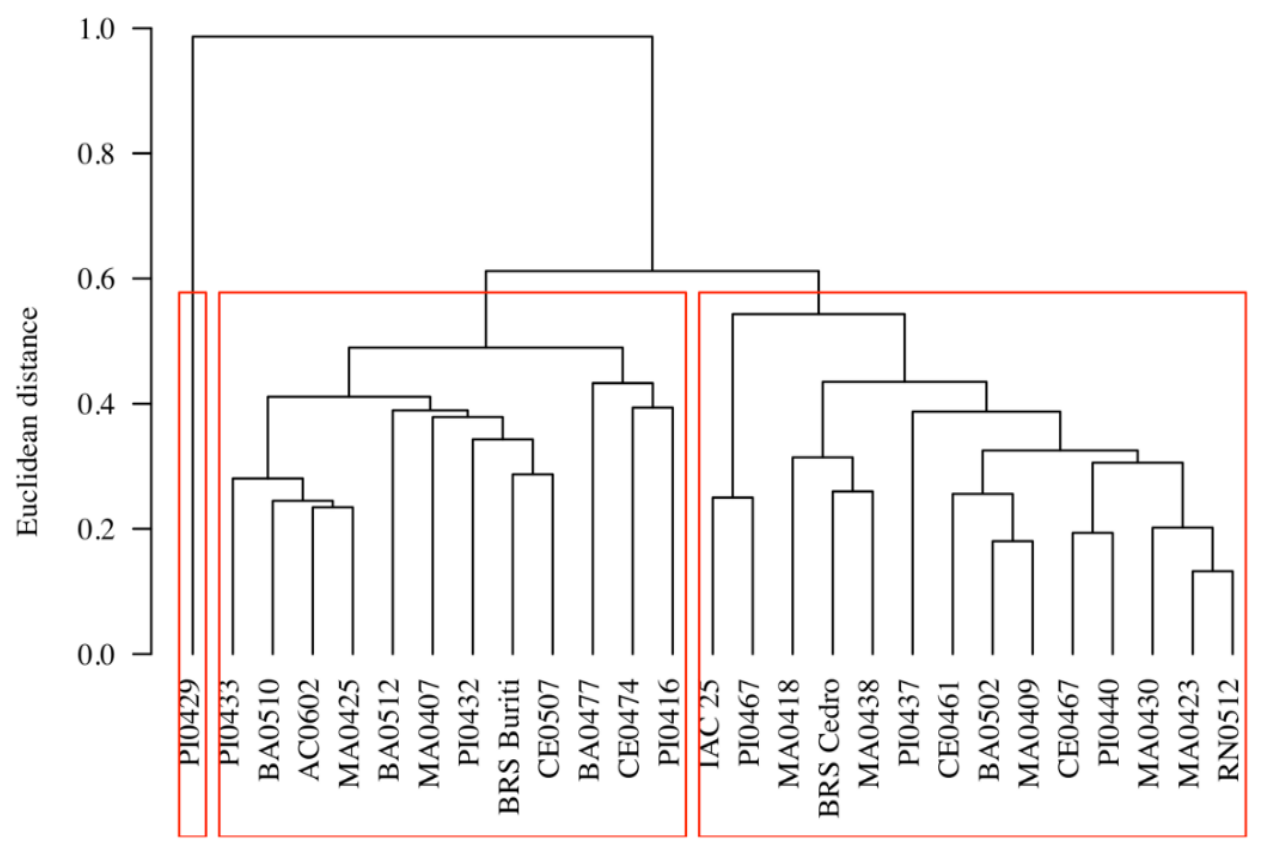

Fig 2. Dendrogram resulting from UPGMA multivariate cluster analysis (Euclidian distance), based on the attractiveness mean of Spodoptera frugiperda (Lepidoptera: Noctuidae) in no-choice test in 27 cotton genotypes. 
Table 3. Number $\left(\mathrm{cm}^{2}\right)$ of trichomes and gossypol glands in 27 cotton genotypes.

\begin{tabular}{|c|c|c|c|c|}
\hline \multirow[t]{2}{*}{ Genotypes } & \multicolumn{2}{|l|}{ Trichomes } & \multicolumn{2}{|l|}{ Gossypol Glands } \\
\hline & Adaxial & Abaxial & Adaxial & Abaxial \\
\hline IAC25 & $6.25 \pm 6.25 c$ & $16.25 \pm 9.56 \mathrm{e}$ & $61.00 \pm 4.18 b$ & $69.25 \pm 6.26 \mathrm{c}$ \\
\hline MA0430 & $24.75 \pm 1.80 \mathrm{c}$ & $67.50 \pm 10.52 \mathrm{~d}$ & $65.25 \pm 8.73 b$ & $83.00 \pm 6.49 b$ \\
\hline PI0467 & $93.25 \pm 30.16 b$ & $139.75 \pm 32.47 \mathrm{c}$ & $49.25 \pm 5.19 c$ & $70.75 \pm 6.81 \mathrm{c}$ \\
\hline RN0512 & $1.25 \pm 1.25 \mathrm{c}$ & $1.75 \pm 1.75 \mathrm{e}$ & $37.25 \pm 9.85 c$ & $55.50 \pm 6.12 \mathrm{c}$ \\
\hline MA0418 & $21.50 \pm 7.66 \mathrm{c}$ & $60.00 \pm 7.31 \mathrm{~d}$ & $69.00 \pm 6.65 \mathrm{~b}$ & $89.75 \pm 9.33 \mathrm{~b}$ \\
\hline MA0425 & $33.25 \pm 4.33 c$ & $62.25 \pm 7.36 \mathrm{~d}$ & $73.25 \pm 7.39 \mathrm{~b}$ & $97.50 \pm 5.17 b$ \\
\hline MA0438 & $9.25 \pm 4.55 \mathrm{c}$ & $28.25 \pm 8.13 \mathrm{e}$ & $6.00 \pm 1.29 \mathrm{~d}$ & $17.50 \pm 2.60 \mathrm{~d}$ \\
\hline BRS Buriti & $20.75 \pm 13.10 c$ & $30.00 \pm 9.91 \mathrm{e}$ & $56.50 \pm 25.34 \mathrm{~b}$ & $103.00 \pm 13.53 b$ \\
\hline MA0409 & $50.25 \pm 13.85 c$ & $124.25 \pm 22.86 \mathrm{c}$ & $93.00 \pm 21.30 \mathrm{a}$ & $109.00 \pm 9.25 \mathrm{a}$ \\
\hline BRS Cedro & $33.25 \pm 8.58 c$ & $35.75 \pm 7.69 \mathrm{e}$ & $103.00 \pm 16.79 \mathrm{a}$ & $143.75 \pm 13.58 \mathrm{a}$ \\
\hline PI0429 & $3.75 \pm 2.50 \mathrm{c}$ & $7.50 \pm 3.12 \mathrm{e}$ & $41.00 \pm 6.54 \mathrm{c}$ & $77.00 \pm 8.70 \mathrm{~b}$ \\
\hline BA0477 & $40.00 \pm 16.27 c$ & $176.00 \pm 24.77 \mathrm{c}$ & $86.00 \pm 5.49 a$ & $115.75 \pm 11.99 a$ \\
\hline CE0474 & $60.75 \pm 6.25 c$ & $94.50 \pm 6.14 \mathrm{~d}$ & $69.00 \pm 6.10 \mathrm{~b}$ & $112.75 \pm 8.89 \mathrm{a}$ \\
\hline MA0407 & $43.00 \pm 9.60 \mathrm{c}$ & $70.00 \pm 4.55 \mathrm{~d}$ & $103.50 \pm 4.59 a$ & $96.75 \pm 4.27 \mathrm{~b}$ \\
\hline PI0416 & $257.75 \pm 61.48 \mathrm{a}$ & $293.75 \pm 26.74 a$ & $46.25 \pm 6.79 \mathrm{c}$ & $65.00 \pm 4.85 c$ \\
\hline CE0467 & $4.00 \pm 1.47 \mathrm{c}$ & $15.25 \pm 6.49 \mathrm{e}$ & $7.50 \pm 3.88 \mathrm{~d}$ & $22.00 \pm 3.81 \mathrm{~d}$ \\
\hline MA0423 & $140.00 \pm 20.28 b$ & $230.00 \pm 15.8 b$ & $70.50 \pm 18.52 \mathrm{~b}$ & $95.00 \pm 18.27 \mathrm{~b}$ \\
\hline PI0440 & - & - & $27.00 \pm 12.16 \mathrm{c}$ & $53.00 \pm 8.45 c$ \\
\hline BA0502 & $63.25 \pm 13.35 c$ & $157.75 \pm 44.54 \mathrm{c}$ & $65.00 \pm 6.47 \mathrm{~b}$ & $96.75 \pm 6.26$ b \\
\hline CE0461 & $26.75 \pm 7.77 \mathrm{c}$ & $116.50 \pm 9.68 c$ & $79.75 \pm 17.78 b$ & $111.25 \pm 9.45 \mathrm{a}$ \\
\hline BA0512 & $7.75 \pm 6.49 \mathrm{c}$ & $14.50 \pm 8.43 \mathrm{e}$ & $65.25 \pm 9.97 \mathrm{~b}$ & $82.75 \pm 8.44$ b \\
\hline BA05101 & $5.25 \pm 3.35 c$ & $28.25 \pm 5.68 \mathrm{e}$ & $44.75 \pm 8.63 \mathrm{c}$ & $45.75 \pm 5.51 \mathrm{c}$ \\
\hline PI0433 & $116.75 \pm 47.47 \mathrm{~b}$ & $137.00 \pm 28.07 c$ & $111.75 \pm 16.33 a$ & $135.25 \pm 14.63 \mathrm{a}$ \\
\hline CE0507 & $45.50 \pm 5.25 c$ & $201.50 \pm 48.29 b$ & $99.00 \pm 21.33$ a & $124.50 \pm 23.26 \mathrm{a}$ \\
\hline PI0432 & $4.25 \pm 1.65 \mathrm{c}$ & $5.00 \pm 1.47 \mathrm{e}$ & $8.00 \pm 6.36 \mathrm{~d}$ & $14.50 \pm 4.41 \mathrm{~d}$ \\
\hline PI0438 & $4.25 \pm 2.10 c$ & $26.00 \pm 5.12 \mathrm{e}$ & $6.00 \pm 2.68 d$ & $14.75 \pm 5.92 \mathrm{~d}$ \\
\hline AC0602 & $0.50 \pm 0.29 c$ & $2.75 \pm 1.18 \mathrm{e}$ & $26.50 \pm 7.38 \mathrm{c}$ & $59.00 \pm 15.76 \mathrm{c}$ \\
\hline $\mathrm{F}$ & 98.968 & 18.664 & 70.809 & 12.745 \\
\hline$P$ Value & $<0.0005$ & $<0.0005$ & $<0.0005$ & $<0.0005$ \\
\hline
\end{tabular}

Table 4. Correlations between the attractiveness of $S$. frugiperda, in free-choice and no-choice tests, and $i$ ) the number of trichomes and $i i$ ) the number of gossypol glands, obtained on the adaxial and abaxial sides of the leaf in cotton genotypes.

\begin{tabular}{|lllll|}
\hline & Attractiveness & & Nonchoice \\
& Free-choice & & $r^{1}$ & $P$ Value \\
\hline Attractiveness X T. Adaxial & $r^{1}$ & $P$ Value & $0.18^{\text {ns }}$ & 0.35 \\
\hline Attractiveness X T. Abaxial & $-0.04^{\text {ns }}$ & 0.85 & $0.10^{\text {ns }}$ & 0.62 \\
\hline Attractiveness X Gossypol AD. & $-0.11^{\text {ns }}$ & 0.94 & $0.11^{\text {ns }}$ & 0.59 \\
\hline Attractiveness X Gossypol AB. & $0.12^{\text {ns }}$ & 0.54 & $0.05^{\text {ns }}$ & 0.80 \\
\hline
\end{tabular}

${ }^{1}$ Correlation coefficient; ${ }^{\mathrm{ns}}$ not differ statistically by $T$-test at $5 \%$ probability. $\mathrm{T}$. = Trichomes; $\mathrm{AD}=\mathrm{Adaxial} ; \mathrm{AB}=\mathrm{Abaxial}$.

morphological characteristics such as color, type of epidermis, presence or absence of trichomes (Seifi et al., 2013; Smith, 2005).

Among the plant morphological characteristics, the presence or absence of trichomes has been associated with antixenosis in several plant varieties (Handley et al., 2005). In cotton, the trichome density has been studied as a source of antixenosis, affecting the insects' feeding and oviposition behavior. Whitefly (Bemisia tabaci biotype B Hemiptera: Aleirodidae) have a preference for ovipositing in cotton plants with a high trichome densities (Prado et al., 2015; Toscano et al., 2003). Cotton with a large amount of trichomes decrease the mobility of $1^{\text {st }}$ instar Chloridea virescens (Lepidoptera: Noctuidae) (Ramalho et al., 1984).

The PI0416 genotype showed the highest trichome density on both adaxial and abaxial surfaces, while the attractiveness of $S$. frugiperda to this genotype was intermediary, thus this morphological characteristic seems to have no influence to the pest behavior. On the other hand, the genotype PI0440, which was characterized as glabrous, had the lowest attractiveness to $S$. frugiperda. The genotypes RN0512, MA0418, CE0467 and BA0502, which were repellent to $S$. frugiperda, showed the lowest trichome densities. Thus the absence of trichomes seem to be a source of antixenosis.

Another cause of resistance in cotton is the presence of allelochemicals, mainly the terpenoid gossypol (Campos et al., 2012). In the present study, the genotypes PI0433, CE0507, MA0407, BA0477 and MA0409 and the cultivar BRS Cedro showed a greater amount of gossypol glands in the adaxial surface and BRS Cedro and the genotypes PI0433, CE0507, BA0477, CE0474, CE0461 and MA040 in the abaxial 
surface. The terpenoid gossypol do not seem to impede the attractiveness of $S$. frugiperda, since the genotypes PI0433, CE0507 and MA0407, which showed a high number of gossypol glands, were the most attractive to $S$. frugiperda. Thus, the gossypol content do not drive the pest behavior, as was also verified for boll weevil particularly for gossypol as for others terpenoid aldehydes (Magalhães et al., 2020).

Other differences among genotypes may explain attractiveness, such as other secondary compounds (nitrogenous, phenolic, terpenoids, organic acids, lipids) and cell wall thickness and hardness (Styrsky et al., 2006). Gossypol glands may not affect the feeding behavior of $S$. frugiperda, because insects such as caterpillars develop morphological and behavioral characteristics to overcome the defense imposed by plant (Young and Moffett, 1979).

UPGMA analysis in free-choice and no-choice tests, separated the genotypes in different levels of resistance to S. frugiperda, showing to be an important tool to complement the univariate methods in the screening of plants resistant to insects (Pitta et al., 2010). In general, it was observed that the genotypes IAC 25, PI0467, MA0418, MA0438, PI0437, CE0461, BA0502, MA0409, CE0467, PI0440, MA0430 and RN0512 were classified as moderately resistant (antixenosis) to $S$. frugiperda.

\section{Materials and Methods}

\section{Colony of Spodoptera frugiperda}

The study was conducted at the Integrated Pest Management Laboratory of the Goiano Federal Institute (Instituto Federal Goiano), Campus Urutaí, Urutaí, Goiás State, Brazil.

Insects obtained from the Embrapa Arroz e Feijão Entomology Laboratory were used to develop a colony. The pupae were sexed and placed in $20 \mathrm{~cm}$ high $\times 10 \mathrm{~cm}$ diameter PVC cages, lined internally with paper (oviposition substrate) for emergence and mating. The adults were fed on $10 \%$ honey solution, placed in plastic containers (PET bottle cap), soaked in cotton and changed every two days. The newly hatched caterpillars were placed in $150 \mathrm{~mL}$ plastic pots containing an artificial diet (Kasten Junior et al., 1978). After reaching the $3 \mathrm{rd}$ instar caterpillars were individualized in plastic containers $(50 \mathrm{~mL})$ until the pupal phase. The insects were reared in the laboratory at $25 \pm 2{ }^{\circ} \mathrm{C}, 70 \pm 10 \%$ $\mathrm{RH}$, and 12:12 h (L:D).

\section{Plant material}

The twenty-seven cotton genotypes of the Gossypium hirsutum species, obtained from the Embrapa Cotton Germplasm Bank (Table 1), were planted and conducted grown under field conditions in an experimental area, at the Instituto Federal Goiano, Campus Urutaí (17\%29'10"S in latitude and 48.12 ' $38^{\prime \prime} \mathrm{W}$ in longitude at $823 \mathrm{~m}$ altitude).

The seeds were scarified and sown in plastic bags $(1 \mathrm{~L})$ with substrate (3: 1: 1 - soil, sand and cattle manure), containing three seeds and thinned out 30 days after planting (DAP). At 45 DAP they were transplanted to the field in an irrigated area. Leaves were obtained from these plants that did not receive insecticide spraying in field.

The attractiveness in free-choice test was performed with $3^{\text {rd }}$ instar caterpillars, offering leaf discs (2.5 diameter) of the cotton genotypes $(n=27)$ to $S$. frugiperda. The leaves were collected in the apical part of the plant and distributed equidistantly in a circular arena $(70 \mathrm{~cm}$ in diameter, and 6 $\mathrm{cm}$ in height) on moistened filter paper in controlled temperature of $25^{\circ} \mathrm{C} \pm 2$, photoperiod $(12 \mathrm{~h}$ ) and humidity $(70 \% \pm 10)$.

The attractiveness in no-choice test was performed offering one leaf disc (2.5 diameter) per arena (Petri dish $9 \mathrm{~cm}$ in diameter). In both tests, the attractiveness was assessed by counting the number of caterpillars feeding on each leaf disk at $3,5,10,15,30$ minutes and 1, 2, 6, 12 and 24 hours after release. In the free-choice test the experiment was set in a randomized block design with 27 treatments (genotypes) and 20 replicates (arenas) with two caterpillars per genotype. In non-choice test, a completely randomized design with 18 treatments (genotypes) and 20 replicates was used with one caterpillar per genotype.

\section{Morphological characteristics - trichome density and gossypol glands}

Two leaves of each genotype were collected in the median region of the plant 30 days after sowing. The average trichome numbers and gossypol glands per $\mathrm{cm}^{2}$ were analyzed in abaxial and adaxial leaf surfaces, both close to the central vein, using a stereoscope microscope (Bel Photonics, Model SZ B LED 89/336, Piracicaba, São Paulo, Brazil).

\section{Statistical analysis}

Residual normality and homoscedasticity were evaluated by the Shapiro-Wilk and Bartlett tests. The attractiveness and morphological data were analyzed by Anova and means compared by the Scott Knott test $(\mathrm{P} \leq 0.05)$. The $t$-test was used to check the correlation between $i$ ) the attractiveness in free-choice test and trichome density; ii) the attractiveness in no choice test and trichome density; iii) the attractiveness in free-choice test and the number of gossypol glands and iv) the attractiveness in the no choice test and the number of gossypol glands. The four comparisons were performed independently for abaxial and adaxial leaf surfaces. A cluster analysis was performed using the Hierarchical Cluster Analysis - UPGMA method based on the Euclidian distance to determine the degree of resistance between the cotton genotypes to $S$. frugiperda. All statistical analyses were performed using R program ( $R$ Core Team, 2019). The attractiveness index for $S$. frugiperda was determined using the formula: $I P=2 A /(M+A)$, where: A = Consumption in the genotype and $M=$ susceptibility pattern (BRS Cedro) (Kogan and Goeden, 1970). A genotype was classified as a stimulant if its index was greater than 1 , neutral if equal to 1 and deterrent if less than 1.

\section{Conclusions}

The genotypes NR0512, MA0418, CE0467 and BA0512 presented characteristics of antixenosis to $S$. frugiperda. The high trichome densities and the number of gossypol glands in cotton plants do not determine the attractiveness of $S$. frugiperda. These cotton genotypes can be used in future study in plant breeding program as donor source of resistance to $S$. frugiperda.

\section{Acknowledgments}

The Fundação de Amparo a Pesquisa do Estado de Goiás FAPEG, for granting a scholarship to the first author. To the National Council for Scientific and Technological Development - CNPq, Brazil, for the research productivity scholarship to the authors FGJ and IPPM and to the Instituto 
Federal Goiano for the financial support for carrying out the research.

\section{References}

Baldin ELL, Vendramim JD, Lourenção A L (2019) Resistência de plantas a insetos: fundamentos e aplicações. FEALQ, Piracicaba, BRA.

Bastos CS, Suinaga FA, Vieira RM, Lima EF (2008) Resistência de algodoeiro a artrópodes-praga. In: Beltrão NEM, Azevedo DMP (eds.) O Agronegócio do algodão no Brasil. EMBRAPA, Brasília. p.355-412.

Campos ZR, Boiça-Júnior AL, Valério Filho WV, Campos OR, Campos, AR (2012) The feeding preferences of Spodoptera frugiperda (J. E. Smith) (Lepidoptera: Noctuidae) on cotton plant varieties. Acta Sci-Agron. 34:125-130.

Freire EC (2007) História do algodão no Cerrado. In: Freire EC (ed.) Algodão no cerrado do Brasil. Associação Brasileira dos Produtores de Algodão, Brasília. pp. 21-52.

Giband M, Dessauw D, Barroso PAV (2010) Cotton: Taxonomy, origin and domestication. In: Wakelyn PJ, Chaudhry MR (eds.) Cotton: Technology for the 21st century. International Cotton Advisory Committee, 3-15.

Handley R, Ekbom B, Agren, J (2005) Variation in trichome density and resistance against a specialist insect herbivore in natural populations of Arabidopsis thaliana. Ecol Entomol. 30:284-292.

Hoffmann-Campo CB, Harborne JB, Mccaffery AR (2001) Preingestive and post-ingestive effects of soybean extracts and rutin on Trichoplusia ni growth. Entomol Exp Appl. 98:181-194.

Jesus FF, Boiça Junior AL, Alves GCS, Busoli AC, Zanuncio JC (2014) Resistance of cotton varieties to Spodoptera frugiperda (Lepidoptera: Noctuidae). Rev Colomb Entomol. 40:158-163.

Kasten Junior AA, Precetti CM, Parra JRP (1978) Dados biológicos comparativos de Spodoptera frugiperda em duas dietas artificiais e substrato natural. Brazilian Journal of Agriculture. 53:68-78.

Kogan M, Goeden RD (1970) The host-plant range of Lema Trilineata daturaphila (Coleoptera: Chrysomelidae). Ann Entomol Soc Am. 63:1175-1180.

Liu B, Wendel JF (2002) Non-Mendelian phenomena in allopolyploid genome evolution. Curr Genomics. 3:1-17.

Magalhães DM, Borges M., Laumann RA, Caulfeld, JC, Birkett MA, Blassioli-Moraes, MC (2020) Inefficient weapon-the role of plant secondary metabolites in cotton defence against the boll weevil. Planta. 252(94):1-15.

Menezes IPP, Hoffmann LV, Lima TH, Silva AR, Lucena VS, Barroso PAV (2017) Genetic diversity of arboreal cotton populations of the Brazilian semiarid: a remnant primary gene pool for cotton cultivars. Genet Mol Res. 16:1-13.

Menezes IPP, Barroso PAV, Silva JO, Hoffmann LV (2015) Distribuição do modo de ocorrência in situ de landraces de algodoeiro Semiárido Brasileiro. Multi-Science Journal. 1:39-47.
Menezes IPP, Gaiotto FA, Hoffmann LV, Ciampi AY (2014) Genetic diversity and structure of natural populations of Gossypium mustelinum, a wild relative of cotton, in the basin of the De Contas River in Bahia, Brazil. Genetica. 142:99-108.

Menezes IPP, Barroso PAV, Hoffmann LV, Lucena VL, Giband M (2010) Genetic divertisy of mocó cotton (Gossypium hirsutum r. marie galante) from the northeast of Brazil: implications for conservation. Botany. 88:765-773.

Moreno DB, Boiça Junior AL, Jesus FG, Janini JC (2008) Resistência de cultivares de algodoeiro a Spodoptera frugiperda (J.E Smith, 1797) (Lepidoptera:Noctuidae). Brazilian Journal of Agriculture. 84:214-224.

Pitta RM, Boiça Junior AL, Jesus FG, Tagliari SRA (2010) Seleção de genótipos resistentes de amendoinzeiro a Anticarsia gemmatalis Hübner (Lepidoptera: Noctuidae) com base em análises multivariadas. Neotrop Entomol. 39:260-265.

Prado JC, Penaflor MFGV, Cia E, Vieira SS, Silva KI, CarliniGarcia LA, Lourenção, AL (2015) Resistance of cotton genotypes with different leaf colourisepiand trichome density to Bemisia tabaci biotype B. J Appl Entomol. 140:405-413.

R Development Core Team R: A Language and Environment for Statistical Computing. R Foundation for Statistical Computing, Vienna, 2019

Ramalho FS, Parrot WL, Jenkins JN, Mccarty Júnior JC (1984) Effects of cotton leaf Trichomes on the mobility of newly hatched tobacco budworms (Lepdoptera: Noctuidae). J Econ Entomol. 77:619-621.

Seifi A, Visser RGF, Yuling BAl (2013) How to effectively deploy plant resistances to pests and pathogens in crop breeding. Euphytica. 190:321-334.

Silva JPGF, Baldin ELL, Canassa VF, Souza ES; Lourenção AL (2014) Assessing antixenosis of soybean entries against Piezodorus guildinii (Hemiptera: Pentatomidae). Arthropod-Plant Inte. 8:349-359.

Smith CM (2005) Plant resistance to arthropods: molecular and conventional approaches. Springer, Berlin. 423 p.

Stephens SG (1973) Geographical distribution of cultivated cottons relative to probable centers of domestication in the new world. In: Adrian M (ed) Genes, enzymes and populations. Plenum Press, p. 239-254.

Styrsky JD, Kaplan I, Eubanks MD (2006) Plant trichomes indirectly enhance tritrophic interactions involving a generalist predator, the red imported fire ant. Biol Control. 36:375-384.

Toscano LC, Santos TM, Boiça Junior AL (2003) Preferência de Bemisia tabaci biótipo B para oviposição em cultivares de algodoeiro. Pesquisa Agropecuaria Brasileira. 38:155160.

Yang G, Isenhour DJ, Espelie KE (1991) Activity of maize leaf cuticular lipids in resistance to leaf-feeding by the fall armyworm. Fla Entomol. 74:229-236.

Young AM, Moffett MW (1979) Studies on the population biology of the tropical butterfly Mechanitis isthmia in Costa Rica. Am Midl Nat. 101:309-319. 